\title{
ABOUT AUTHORITY, WHICH DIDN'T WANT TO TAKE RESPONSIBILITY (SOME TRADITIONS AND CASES IN THE LAW SYSTEM OF MEDIEVAL FREIBURG)
}

\author{
Pavel A. Blokhin \\ Astrakhan State University, Astrakhan, Russian Federation
}

\begin{abstract}
Urban law is a unique phenomenon in the life of medieval western society. When you study the history of medieval law initiation and progression, it is important to investigate the legal sources. Traditions is one of such sources (reference to eternity and ancientry of laws). In Freiburg legal system such reference existed in the form of pointing out the borrowing local law regulations from the so-called Cologne law. Thus, Cologne officially became maternal city for Freiburg. However, this tradition didn't result in law filiation. As the years passed the provisions of law have changed. New regulation referred to Cologne as a place of the arbitration court for Freiburg inhabitants, not as a model city in a legal sense. Legal practice confirms this rule in the legislation.

Firstly, the special regulatory act imposing the procedure of applying to Cologne arbitration court was established. The decision on application was made by the burghermaster and City council.

Secondly, there are at least three fortuitous events - the responses of Cologne authorities to Freiburg Council with regard to these three cases. These include murder cases, cases over infliction of serious bodily injury or harm and theft offences. The documents don't contain judgment, and the two of them contain arbitrators' references about the need to apply Cologne legal proceedings.

The uniqueness of this case consists in the fact that new regulation was established during the period of legal paradigm shift, when the judicial proceedings were transformed from archaic into rational ones.

Key words: middle ages, medieval town, medieval urban law, Freiburg in Breisgau, legal traditions and cases.

Citation. Blokhin A.P. About Authority, Which Didn't Want to Take Responsibility (Some Traditions and Cases in the Law System of Medieval Freiburg). Vestnik Volgogradskogo gosudarstvennogo universiteta. Serija 4, Istorija. Regionovedenie. Mezhdunarodnye otnoshenija [Science Journal of Volgograd State University. History. Area Studies. International Relations], 2017, vol. 22, no. 3, pp. 42-51. (in Russian). DOI: https://doi.org/10.15688/jvolsu4.2017.3.4.
\end{abstract}

\section{О ВЛАСТИ, КОТОРАЯ НЕ ХОТЕЛА БРАТЬ ОТВЕТСТВЕННОСТЬ НА СЕБЯ (НЕКОТОРЫЕ ТРАДИЦИИ И КАЗУСЫ В ЮРИДИЧЕСКОЙ СИСТЕМЕ СРЕДНЕВЕКОВОГО ФРАЙБУРГА)}

\author{
Павел Александрович Блохин
}

Астраханский государственный университет, г. Астрахань, Российская Федерация 
Аннотация. Городское право - уникальное явление в жизни средневекового западного общества. Важным моментом в изучении истории возникновения и развития права в средневековом городе является вопрос об источниках самого права. Одним из таких источников следует назвать традиции (отсылка к «вековечности» и «древности» законов). В городском праве средневекового Фрайбурга в Брайсгау подобная отсылка существовала в том числе в виде указания на заимствование местных правовых норм от так называемого права города Кёльна. Кёльн, таким образом, официально становился материнским для Фрайбурга городом. Однако такая традиция не привела к созданию филиации права. С течением времени норма изменилась. Новое правило указывало на Кёльн не как на образцовый в юридическом отношении город, а как на место третейского суда для фрайбуржцев. Юридическая практика подтверждает данное правило в законодательстве.

Во-первых, был создан специальный нормативный акт, устанавливающий процедуру обращения в третейский иногородний (кёльнский) суд. Решение об обращении принималось бургомистром и городским советом.

Во-вторых, существует по крайней мере три казуса - ответа кёльнских городских властей на обращение фрайбургского совета по трем делам. Это дела об убийстве, о нанесении тяжких телесных повреждений и о краже. Документы не содержат вердикта, в двух из них есть рекомендация третейских судей о необходимости применить судебную процедуру, принятую в Кёльне.

Уникальность данного случая заключается в том, что новое правило возникло в период смены правовой парадигмы, когда судебный процесс превращался из архаического в рациональный.

Ключевые слова: средние века, средневековый город, средневековое городское право, Фрайбург в Брайсгау, юридические традиции и правовые казусы.

Цитирование. Блохин П. А. О власти, которая не хотела брать ответственность на себя (некоторые традиции и казусы в юридической системе средневекового Фрайбурга) // Вестник Волгоградского государственного университета. Серия 4, История. Регионоведение. Международные отношения. - 2017. - Т. 22, № 3. - C. 42-51. - DOI: https://doi.org/10.15688/jvolsu4.2017.3.4.

Репрезентация публичной власти должна осуществляться с помощью правил. Эти правила появлялись в силу существующей традиции, и в процессе своего развития могли сами становиться традицией. Правила должны иметь свое обоснование. Если посчитать средневековое городское право правилом и традицией в репрезентативной (и не только!) функции публичной городской власти, то такими обоснованиями можно полагать и волю сеньора города/муниципального управления, и ссылку на древность и вековечность закона, и казусы местного судопроизводства [3, c. 234]. Из этого перечня обоснований легитимности права ссылка на вековечность и происхождение вызывает интерес тем, что создатели законов обращаются к традиции «воспоминания» закона. Включается механизм исторической памяти.

\section{Эпизод І. Правило и традиция}

В средневековом городе Фрайбурге в Брайсгау действовало городское право. Оно появилось в 1120 г., когда господин Конрад, младший брат фрайбургского сеньора, герцо- га Бертольда фон Церинген, в то время томившегося в плену у кёльнского архиепископа, предоставил городу так называемую Учредительную привилегию [9, S. 531-534]. Фрайбургская Учредительная привилегия документ, представляющий несомненный интерес для исследователя, занимающегося историей раннего города немецкого юго-запада [2, c. 22-23].

В Учредительной привилегии нет прямого указания на вековечность и древность права. Фрайбург возник между 1008 [19, S. 3-6] и 1091-1120 гг. [22, S. 6-7]. Это было поселение близ замка, и, разумеется, в полной мере юридические традиции сложиться еще не могли. Господин Конрад указывает в тексте пролога к Учредительной привилегии, что «в местечке, именуемом (досл. - [что] разумеется) Фрайбург, по собственному праву основал рынок [в] году от воплощения Господа 1120» [9, S. 531]. В этом пассаже зафиксирована воля сеньора, дающего право, и абсолютно исключена ссылка на древность и вековечность действующих в данном месте законов.

По всей видимости, чтобы Учредительная привилегия стала впоследствии «добрым 
старым правом», одной воли сеньора было мало. Тогда для решения этой задачи в качестве образцового закона, на который стоит ориентироваться, господин Конрад выбрал право города Кёльна. Сеньор Фрайбурга обещает, что будет решать все споры, которые могли бы возникнуть в купеческой среде, в соответствии с кёльнским законодательством. Вот дословный текст этой правовой нормы:

И если где будет иметь место ссора между горожанами моими или [будет подана] жалоба, [то] разбирать [дело будет] не только сообразно моему решению или тамошнего наместника, но рассмотрено будет по обычному и законному праву всех купцов, особенно же кёльнских [9, S. 532-533].

Это без преувеличения один из самых сложных для анализа параграфов фрайбургского средневекового права. В 1120 г. «обычное и законное право... купцов... кёльнских», скорее всего, не было записано, если не брать в расчет некоего истлевшего и изъеденного червями пергамена, который магистры горожан, кёльнские скабины и официалы Рихерцехе нехотя достали из сундука в 1169 г. $[6$, с. $64 ; 8$, с. 79$]$ по требованию тамошнего архиепископа Филиппа. Документ, который кёльнцы восстановили и дополнили, совсем не похож на запись обычного и купеческого городского права, а скорее, действительно напоминает договор между власть имущими о разделе полномочий и, соответственно, доходов. С другой стороны, остается вероятность, что настоящего документа просто не существовало и речь идет о некой мистификации политической интриге, в результате которой городские чиновники «нехотя» достали «истлевший» и «изъеденный червями» пергамен, составленный ими самими и ими же специально доведенный до такого состояния. Любые предположения так и останутся предположениями, и с определенностью можно утверждать только одно: зафиксированного на пергамене «обычного и законного права... купцов... кёльнских», которое можно датировать концом XI в. - 1120 г., ныне не существует. «Расшифровать» же запись о приоритете кёльнского права над фрайбургским можно только при помощи догадок, коих, кстати, было много.
Одна из таких догадок была высказана теми, кто в настоящее время пытается популяризовать фрайбургскую историю в сети Интернет [12]. Старший брат господина Конрада, герцог Бертольд III фон Церинген, находился в это время в плену у кёльнского архиепископа. Условия плена были отнюдь не тяжелые, и, дав честное слово не бежать из Кёльна, герцог Конрад мог свободно передвигаться по городу. Поразившись красотой убранства местных церквей и подивившись богатству горожан, Бертольд решил завести у себя во Фрайбурге кёльнские порядки, посоветовав младшему брату дать Фрайбургу Учредительную привилегию, которая должна быть основана именно на кёльнском праве.

Л.Н. Беркут, рассматривая вопрос о степени включения фрайбургского права в систему немецкого императорского и частновладельческого городского законодательства в XII в., посчитал это обращение к кёльнскому праву за пустую фикцию. Исследователь полагал, что подобная запись в древнейшей хартии во фрайбургском законодательстве не имела никакого практического смысла, а историки столкнулись с опытом исторической мистификации [1, с. 7]. Л.И. Солодкова, исследуя проблемы истории раннего Кёльна, обратила внимание на спорный параграф фрайбургской Учредительной привилегии [8, с. 79]. Саратовская исследовательница полагает, что кёльнское право, будучи авторитетным в регионе, было безоговорочно принято господином Конрадом фон Церинген. Под кёльнским правом Л.И. Солодкова понимает некие права местной городской общины, добытые горожанами в 1112 г., «возможно, вооруженным путем» [8, с. 79]. То, что фрайбургский сеньор заимствовал кёльнский закон, указывается исследовательницей и в статье о городской общине [7, с. 36]. Я думаю, что в данном случае саратовский историк использовала двойное предположение. Взяв за основу как некий неоспоримый факт ссылку на «обычное и законное право... купцов... кёльнских», историк считает, что кёльнское купеческое право существовало уже в начале XII в. и даже было зафиксировано «в некоей привилегии, по неизвестным причинам не дошедшей до нашего времени» [8, с. 79]. Солодкова также полагает, что бернская конституция первой 
половины XIII в. была составлена на основе кёльнского права [7, с. 36], что в принципе не соответствует действительности. Бернская хартия (Berner Handfeste) была написана по указанию императора Фридриха II Штауфена и в своей основе имела фрайбургские, а не кёльнские законы. Берн входил в так называемую систему фрайбургской правовой семьи.

Немецкие историки XIX в. рассматривали факт обращения к кёльнскому праву как не имеющую особого смысла запись. Говорилось, что указание на кёльнское право чисто механическое действие со стороны авторов фрайбургских хартий [13, S. 68]. Позднее был сделан вывод о том, что в городе было использовано обычное право кёльнских купцов с целью привлечения новопоселенцев [14, S. 3].

Проблем в данном случае действительно много. Кроме того, что кодифицированного кёльнского купеческого и общего права, скорее всего, не существовало, имеется еще много вопросов: почему господин Конрад не принял за образец право такого города, как Майнц, например? Во-первых, этот город географически ближе к Фрайбургу, чем Кёльн. Во-вторых, как указывает Г. Бюттнер, этот город (как и Регенсбург) в начале XII в. в своем социально-экономическом развитии не на много пропустил вперед пресловутый Кёльн. Хотя тот же Бюттнер утверждает, что Фрайбург был теснее связан с экономикой Кёльна, нежели Регенсбурга или Майнца [10, S. 7-10]. В-третьих, к XI-XII вв. в Верхнем Рейне сложилась определенная правовая традиция. Эта традиция ориентировала только что основанные города региона обращаться к праву Вормса и Майнца как к материнскому законодательству. Об этом со ссылкой на ранние хартии (X-XI вв.) частновладельческих городов региона говорит О. Фегер [11, S. 24].

$$
* * *
$$

Господин Конрад фон Церинген сформулировал правило. Его наследники - герцоги Церинген, графы фон Фрайбург, немецкие короли и императоры превратили это правило в традицию. Вот как выглядела письменная традиция во фрайбургской хартии 1218 г. $[4$, с. $17-40 ; 23$, S. $3-25]$ :
Да будет известно всем, как нынешним, так и будущим, что Бертольд, герцог фон Церинген ${ }^{1}$, решил основать свободный город, то есть Фрайбург, на собственной наследственной земле, согласно праву Кёльна, в году от воплощения Господа 1120 [23, S. 3].

Как можно увидеть, спустя сто лет «обычное и законное право... купцов... кёльнских» превратилось в «право Кёльна», что лучше всего характеризует появившуюся традицию. В дальнейшем традиция не менялась. В дополнениях к Stadtrodel'ю от 1248 г. говорится, что Фрайбург был основан «в соответствии с правом Кёльна» [23, S. 53]. В тексте из Бремгартена [4, с. 17-40; 17, S. 30-45] официальной копии ряда фрайбургских хартий, составленной в начале XIII в. - запись выглядит так:

Если случится между горожанами спор или ссора, то она будет разрешена согласно обычному праву всех купцов, окончательное решение будет за кёльнским правом [17, S. 30].

Немецкоязычный проект городского права 1275 г. указывает, что «закон города Фрайбурга в Брайсгау был написан в соответствии с [древнейшим] правом и свободами города Кёльна» [23, S. 92]. В хартии 1293 г. говорится о «праве города Фрайбурга в Брайсгау, дарованном по закону города Кёльна» [23, S. 123]. В документах, данных от имени императоров в первой половине XIV в., которые подтверждают прежние городские привилегии, вновь указано на влияние кёльнского права во Фрайбурге ${ }^{2}$. Последнее упоминание о связи кёльнских законов с Фрайбургом зафиксировано в документе 1403 г., данном от имени короля Рупрехта фон Пфальц, подтверждающем старые городские свободы [23, S. 178]. Наконец, многочисленные хартии дочерних городов говорят о взаимосвязи кёльнского права с фрайбургским [9, S. 565-649, 695-700].

$$
* * *
$$

Немецкие историки не выработали единого мнения относительно функционирования этой традиции. Велись дискуссии по вопросу, был ли Фрайбург дочерним городом по отношению к Кёльну. Такого мнения придерживался Т. Маурер [16, S. 178]. Его противники 
В. Шлезингер $[18$, S. 111] и Г. Бюттнер $[10$, S. 7-10] считали такой тезис недоказуемым.

Значительное число мнений по данному вопросу может свидетельствовать только о следующем: историкам неизвестны причины появления юридического правила об обращении во фрайбургском праве к «обычному и законному праву... купцов... кёльнских», а также непонятны механизмы превращения указанного юридического правила в правовую традицию - ссылку на «право Кёльна».

\section{Эпизод II. Новое правило}

Новое правило появилось «из ниоткуда». Историки, обращавшиеся к этому сюжету, не смогли дать исчерпывающего объяснения причин появления этого правила. Оно, так же как и вышеназванное, непостижимым образом обращает фрайбургское право к законам Кёльна. Новая традиция выглядит так:

Если между горожанами возникает спор, так, что одна часть захочет высказаться за, а другая против, то, если хотят, пусть двое из числа двадцати четырех консулов, не обычных горожан, могут уехать за советом в Кёльн. Если они возвратятся из Кёльна с решением от местных жителей, что одна сторона говорит справедливо, то вторая [сторона] должна оплатить все издержки. Если же кёльнский суд не утвердит [такое решение], то они [первая сторона] должны оплатить все издержки $[4$, c. $28 ; 23$, S. 14$]$.

В сущности, эта статья устанавливает процедуру решения спорных дел. Фрайбургские власти постановили, что в городе Кёльне располагается третейский для Фрайбурга суд. Речь идет о разрешении конфликтов между горожанами, которые не смогли урегулировать местные судьи. Это новое правило было создано специально для города Фрайбурга. Дочерние хартии фрайбургской филиации не отсылали представителей в Кёльн за советом. Правовая система Фрайбурга же стремилась «законсервировать» этот закон. В немецкоязычных хартийных текстах 1275 и 1293 гг. составители грамот просто перевели этот параграф с латыни на немецкий [23, S. 135-136].

Среди множества мнений, объясняющих причины появления и механизмы функционирования данного закона, хотелось бы выделить одно. Б. Швинекёпер, ввел в научный оборот источник, датируемый 1389 годом. Это был запрос фрайбургских властей в кёльнский муниципалитет о разъяснении по делу о краже. Историк полагал, что Фрайбург в данном случае использовал кёльнский суд для того, чтобы уменьшить влияние в регионе и городе императорского и королевского права [21, S. 471-489].

В XIII в. в городе Фрайбурге появилось новое юридическое правило, которое предписывало отправлять в третейский суд города Кёльна представительство городской администрации в случае, если местный суд не сможет найти правильное решение по тому или иному уголовному или гражданскому делу. Будет уместным сделать предположение о том, что данная норма возникла как реальный судебный прецедент и имела практический смысл. Вероятно также, что правило об отправке представительства в Кёльн было тесно связано с уже существующей фрайбургской традицией считать кёльнские законы приоритетными.

\section{Эпизод III. Судебная справедливость по-фрайбургски}

Со временем новое правило, созданное как прецедент, перестало удовлетворять вызовы фрайбургского сообщества. Юридическая система продолжала развиваться и пыталась соответствовать своему времени. Работая с текстами так называемой Красной книги - сборника нормативных актов городского совета Фрайбурга - У. Кнефелькамп проанализировал два документа, так или иначе имеющих отношение к новому правилу. Первый источник представляет собой директиву руководство к действию для решения спорных судебных вопросов, предназначенное членам старшего совета и заседателям городского суда:

Если поймают кого-либо как грабителя, то должна собраться коллегия старшего Совета двадцати четырех и заседать 14 дней, а если понадобится, то и более. И когда договорятся, дело передается в суд, и если там судьи не смогут выработать единого мнения, то старший Совет четырнадцати ${ }^{3}$ должен составить письмо в Кёльн. Бургомистр должен назвать представителей от старше- 
го Совета двадцати четырех: от купцов и ремесленников, от тех, кто владеет имуществом - erbe, столько, сколько посчитает нужным < .. >. Они должны принести клятву и допросить вора и свидетелей по делу. И если потребуется, то совет должен послать с подобающим сопровождением делегацию в тот город, в котором [местный] совет может решить дело... ${ }^{4}[15$, S. 95$]$.

Директива, как можно понять, не называет имен, определения тяжести правонарушения, вердикта. Это документ о процедуре судопроизводства, которой следовало строго придерживаться. В документе имеется определенное несоответствие с новым правилом. В «новом правиле» из городской хартии указывается на несогласие в среде горожан непосредственных участников процесса (истцах и ответчиках), из «директивы» же следует, что разногласия могут появиться у городских судий. Мнение горожан, которые были участниками процесса, не учитывалось.

Второй источник - это ответ муниципалитета Кёльна фрайбургскому совету на запрос последнего о разрешении спорных дел: убийства, нанесения тяжких телесных повреждений и кражи. Примечательно, что само письмо было адресовано совету города Кёльна, однако ответ получили от скабината. Поясню, что власть в городе Кёльне была распределена между городским советом, так называемым Рихерцехе («цехом богатых») и скабинатом, которому принадлежали также определенные судебные прерогативы. Скабинат имел право выступать в качестве третейского суда [8, с. 61-74]. Три оригинальных письма фрайбургского совета в Кёльн не сохранились, хотя об их существовании еще в XIX в. писал основатель фрайбургского научного краеведения Г. Шрайбер [20, S. 29-33]. Определенным везением для историка считаю то, что кёльнские судьи пересказали содержание первоначальных запросов своих коллег из Фрайбурга. В документе указано, что кёльнцы дословно цитируют фрайбургские письма, хотя проверить это уже невозможно. Кёльнский текст датирован 1358 годом.

Первый случай, рассказанный в письме фрайбургского совета, был делом об убийстве. На городской рынок пришел человек, который ударил в колокол. Это была установленная процедура. Услышав звон рыночного колоко- ла, на место прибыли члены совета - консулы. Звонивший заявил, что произошло убийство. Эта процедура проходила не вполне в соответствии с установленным законом. Норма указывала, что если нападут на горожанина и он будет ранен, то потерпевший, добравшись на рыночную площадь, обязан ударить в колокол. Члены городского совета должны прибыть на место, омыть раны потерпевшего и удостовериться в ранении, после чего двадцать четыре консула должны начать следствие по делу [4, с. 37; 23, S. 24]. В данном случае произошло убийство, и иск подал обвинитель.

Во фрайбургском кафедральном соборе проводили экстраординарные судебные заседания - так называемый суд крови. Во время его проведения обвиняемый в убийстве, на которого показал ответчик, заявил о своей невиновности. Закон гласил, что в данном случае обвинитель должен был предоставить двух свидетелей - очевидцев преступления. Свидетели должны были быть «достойными». В их число входили лица, принадлежавшие городской общине, а также имеющие незапятнанную репутацию добропорядочных горожан [4, с. 27; 23, S. 13]. У ответчика было право отклонить свидетельские показания. В таком случае решение принималось по итогам судебного поединка [4, с. 29-30; 23, S. 14-15]. Также свидетелей могли отвести сами судьи $[4$, c. $39 ; 17$, S. 45$]$. Так или иначе, но «достойных» свидетелей-горожан, которые это убийство «visu et auditu», не нашлось.

Судебное заседание зашло в тупик. Истец поклялся, что его обвинение истинно. Такую клятву могли в соответствии с законом признать ложной семь опять же «достойных» свидетелей-горожан, которые «visu et auditu» [4, с. 39; 17, S. 42]. Таких не нашлось. Ни одна из сторон не смогла доказать свою точку зрения, и, как было написано в документе, между судьями возник zweyend. Большинство судебных заседателей признали обвиняемого невиновным. Оставшиеся в меньшинстве требовали исполнить закон и судебные процедуры. Первоначальное предложение устроить судебный поединок между обвинителем и обвиняемым было отвергнуто, поскольку противоречило закону [4, с. 37; 23, S. 24]. Ситуация оказалась неразрешимой. Дело передали орга- 
нам исполнительной власти. Для разбирательства были созваны оба городских совета. Дабы не допустить судебной ошибки и не осудить невиновного, советами было решено отправить делегацию в Кёльн под руководством двух достойных жителей Фрайбурга, как оказалось, не простых горожан: Гессе Сневли (родного брата бургомистра, фогта и рыцаря) и Ганнемана Турнера. Кёльнский совет должен был дать удовлетворительный ответ. Необходимо отметить исключительный характер миссии, поскольку речь идет о преступлении, наказание за которое полагалось одно - смертная казнь [4, с. 29-30; 23, S. 1415]. Поэтому был отправлен фогт - Гессе Сневли, по роду своей деятельности не имевший права быть членом городской общины, а значит, человек нейтральный. Фогт - судья, имеющий право разбирать дела, попадавшие в сферу влияния сеньориального и земского права. Личность Ганнемана Турнера не установлена.

Коллегия кёльнских шеффенов предложила собственное процессуальное законодательство для решения спорных дел ${ }^{5}$. В случае с убийством обвиняемый должен был представить семь правоспособных свидетелей или выдержать поединок.

Второе дело, зафиксированное в ответе кёльнцев, - случай с нанесением тяжких телесных повреждений. Был избит горожанин. За этим наблюдало множество очевидцев, но, к счастью для обвиняемого, потерпевший не смог представить в качестве доказательства своего обвинения установленного правом достаточного количества правоспособных свидетелей из числа «достойных» горожан. Большинство судий постановило соблюсти закон и отпустить бузотера. Меньшинство из судейской коллегии решили поверить потерпевшему и предложили осудить обвиняемого. Ни одна из сторон вновь не смогла доказать свою точку зрения, и, как было написано в документе, межу судьями возник zweyend.

Третье дело - случай с кражей. Во Фрайбурге была совершена кража, вора поймать не удалось, но на определенного человека показали свидетели, после чего у обвиненного нашли краденое имущество. Вступал в силу закон о процедуре расследования дела о скупке краденого. Горожанин, опознавший свое имущество, которое ранее было у него украдено, должен был принести клятву со всеми полагающимися свидетельскими показаниями. Обвиненный, в свою очередь, должен был принести клятву в том, что он не знал, что это имущество краденное. Однако же если он приобрел краденную собственность у знакомого, то должен был привести последнего в суд в течение 14 дней. В этой процедуре было то, что не соответствовало всем требованиям дела, так что суд вновь не смог принять однозначного решения. Большинство предложило осудить обвиняемого как скупщика краденного, меньшинство - послать дело на дополнительное расследование. Опять между судьями возник zweyend.

Старший Совет двадцати четырех решил отправить делегацию в Кёльн. Так как скупка краденного или избиение не наказывались во Фрайбурге смертной казнью, был назначен иной состав делегированной комиссии. Возглавляли ее некие Хуг Едерли и Лютфрид Ачер, члены старшего Совета двадцати четырех. Обе делегации - по делу об убийстве и делам по избиению и краже - были отправлены в Кёльн одновременно. Кёльнцы при рассмотрении иска об избиении постановили, что подсудимый должен был представить шесть правоспособных свидетелей или выдержать поединок. Чтобы обвинить вора, истцу требовалось привести с собой в суд двух и более правоспособных свидетелей.

Чем закончились дальнейшие слушанья по этим делам - неизвестно. Хотелось бы отметить, что все три случая - реальные судебные казусы, несмотря на «обезличивание» участников процесса. То, что имена предполагаемых убийцы, скупщика краденого и драчуна, равно как и свидетелей и обвинителей по делу, не были названы, можно объяснить тем, что в случае удачного решения дела для обвиняемых не стоило бросать тень обвинения в чужом суде на достойных фрайбуржцев. И еще один интересный момент. Все три дела не обнаруживают и следа от «суда пыльных ног» - такого необходимого быстрого судопроизводства для купцов и ремесленников, как об этом писала Т.М. Негуляева [5, с. 256-257], что, разумеется, не означает, что «быстрого» и «рационального» суда во Фрайбурге в этот период времени не было вовсе. 
Процессам, которые происходили в середине XIV в. во фрайбургском праве, сложно дать однозначную оценку. Продолжало существовать архаичное, по сути, средневековое городское право со всеми установленными процедурами, клятвами, судебными поединками и свидетельскими показаниями от «достойных» горожан. Это явно не соответствовало только-только появлявшимся представлениям о судебной справедливости, таким как они окончательно сформировались в более поздний период времени, когда возник «человек рациональный». С одной стороны, очевиден примат местного городского права, a c другой - восприятие категории вины вступает в конфликт с действующими правовыми нормами. Перед фрайбургской властью была сложная ситуация: или поступать в соответствии со сложившимися правилами и традициями и, таким образом, сохранить установленный миропорядок, или действовать во благо справедливости и здравого смысла. И тот, и другой варианты были «правильными», однако в данном случае власть не захотела брать ответственности на себя.

\section{ПРИМЕЧАНИЯ}

1 В тексте, вероятнее всего, говорится о герцоге Бертольде III фон Церинген (ум. в 1122 г.), старшем брате господина Конрада.

21315 г. [23, S. 203], 1339 г. [23, S. 343], 1342 г. $[23$, S. 376$]$ и 1357 г. [23, S. 455].

3 По всей видимости, в тексте допущена ошибка. Так называемый старший и младший советы (органы городского самоуправления Фрайбурга) состояли из двадцати четырех членов каждый. Вероятно, составитель документа просто перепутал числительные (vierundzentzig и vierundzwenzig).

4 Документ не датирован.

5 Так считает Кнефелькамп [15, S. 88]. Можно предположить, что кёльнцы действовали в соответствии с фрайбургским законодательством.

\section{СПИСОК ЛИТЕРАТУРЫ}

1. Беркут, Л. Н. Императорские привилегии и городские права XII в. в Германии / Л. Н. Беркут. Варшава : Тип. Варшав. учеб. округа, 1910. - 15 с.

2. Блохин, П. А. «Чужие» в средневековом городе (по материалам фрайбургского городского права) / П. А. Блохин // Вестник Волгоградского го- сударственного университета. Серия 4, История. Регионоведение. Международные отношения. - Т. 19, № 1. - 2014. - C. 22-29. - DOI: http://dx.doi.org/ 10.15688/jvolsu4.2014.1.3.

3. Варьяш, О. И. Городское право и право в городе как фактор единения / О. И. Варьяш // Город в средневековой цивилизации Западной Европы. Т. 3. Человек внутри городских стен. Формы общественных связей. - М. : Наука, 2000. - С. 232-253.

4. Городское право Фрайбурга // Средневековый город : прил. к ежегоднику «Средние века». 2005. - Вып. 1. - С. 17-40 (параллел. текст).

5. Негуляева, Т. М. Зарождение правосознания и чувства личности у немецких бюргеров в XIIXIII веках / Т. М. Негуляева // Город в средневековой цивилизации Западной Европы. Т. 3. Человек внутри городских стен. Формы общественных связей. - М. : Наука, 2000. - С. 254-259.

6. Право г. Кёльна // Средневековое городское право ХІІ-ХІІІ веков : сб. текстов / сост. Т. М. Негуляева, Л. И. Солодкова. - Саратов : Изд-во Сарат. ун-та, 1989. - С. 61-93.

7. Солодкова, Л. И. Городская община: единство и противоречия / Л. И. Солодкова // Средневековый город. - 2004. - Вып. 16. - С. 35-41.

8. Солодкова, Л. И. Ранний Кёльн: социальноэкономическое развитие и освободительная борьба горожан (XI-XIII вв.) / Л. И. Солодкова. - Саратов : Изд-во Сарат. ун-та, 1991. - 148 с.

9. Blattmann, M. Die Freiburger Stadtrechte zur Zeit der Zähringer. Bd. 1-2 / M. Blattmann. - Freiburg ; Würzburg : Verlag Ploetz, 1995. - 772 S.

10. Büttner, H. Freiburg und das Kölner Recht / H. Büttner // Zeitschrift des Breisgau-Geschichtsverein („Schau-ins-Land“). - 1954. - Hf. 72. - S. 7-10.

11. Feger, O. Das älteste Freiburger Stadtrecht im Rahmen der südwestdeutschen Städteentwicklung / O. Feger // Zeitschrift des Breisgau-Geschichtsverein („Schau-ins-Land“). - 1963. - Hf. 81. - S. 18-31.

12. Freiburgs Geschichte in Zitaten. - Electronic text data. - Mode of access: http://www.freiburgsgeschichte.de/1000-1218_Anfaenge.htm (date of access: 12.10 .2014$)$. - Title from screen.

13. Gaupp, E. Th. Über deutsche Städtegründung, Stadtverfassung und Weichbild im Mittelalter, besonders über die Verfassung von Freiburg i. B., verglichen mit der Verfassung von Köln / E. Th. Gaupp. Jena : F. Frommann 1824. - 436 S.

14. Huber, E. Kölnisches Recht in den Zähringerstädten / E. Huber // Zeitschrift für Schweizerisches Recht. - 1882. - Bd. 22. - S. 3-21.

15. Knefelkamp, U. Über Rechtsbeziehungen zwischen Köln und Freiburg im Mittelalter / U. Knefelkamp // Zeitschrift des BreisgauGeschichtsvereins (,Schau-ins-Land“). - 1982. Hf. 101. - S. 87-96. 
16. Mayer-Edenhauser, Th. Das Recht der Liegenschaftsübertragung in Freiburg im Breisgau / Th. Mayer-Edenhauser. - Freiburg : Josef Waibel Verlagsbuchh, 1937. - $354 \mathrm{~S}$.

17. Rietschel, S. Neue Studien über die älteren Stadtrechte von Freiburg im Breisgau mit einer vergleichenden Ausgabe der lateinischen Stadtrechtstexte des 13. Jahrhunderts / S. Rietschel // Festgabe der Tübinger Juristenfakultät für Friedrich von Thudichum zum Fünfzigjährigen Doktorjubiläum 19. August 1907. - Tübingen : Verlag der H. Laupp'schen Buchhandlung, 1907. - $45 \mathrm{~S}$.

18. Schlesinger, W. Das alteste Freiburger Stadtrecht Überlieferung und Inhalt / W. Schlesinger // Zeitschrift der Savigny-Stiftung für Rechtsgeschichte: Germanistische Abteilung. - 1966. - № 83. - S. 63-126.

19. Schreiber, H. Freiburg im Breisgau mit seinen Umgebunden / H. Schreiber. - Freiburg : Herder'sche Kunst- und Buchhandlung, 1832. - $58 \mathrm{~S}$.

20. Schreiber, H. Merkwürdigere bürgerliche Einrichtungen. I. Das Glocken- oder Blutgericht / H. Schreiber // Freiburger Adresskalender für das Jahr 1826. - Freiburg : Herder'sche Kunst- und Buchhandlung, 1826. $-265 \mathrm{~S}$.

21. Schwineköper, H. Bonn, Köln und Freiburg im Breisgau. Bemerkungen zu den mittelalterlichen Beziehungen der Städte / H. Schwineköper // FS Ennen, E. - Bonn : Ludwig Röhrscheid Verlag, 1972. -S. 471-489.

22. Stülpnagel, W. Über neuere Arbeiten zu Fragen der Freiburger Stadtgründung / W. Stülpnagel // Zeitschrift des Breisgau-Geschichtsverein (,Schauins-Land"). - 1970. - Hf. 88. - S. 5-22.

23. Urkundenbuch der Stadt Freiburg im Breisgau. Bd. I, Abt. 1-2 / Hg. H. von Schreiber. Freiburg : Herder'sche Kunst- und Buchhandlung, 1828. $-556 \mathrm{~S}$.

\section{REFERENCES}

1. Berkut L.N. Imperatorskie privilegii i gorodskie prava XII v. v Germanii [Imperial Privileges and City Rights of the $12^{\text {th }}$ Century]. Varshava, Tipografija Varshavskogo uchebnogo okruga, $1910.15 \mathrm{p}$.

2. Blokhin P.A. «Chuzhie» v srednevekovom gorode (po materialam frayburgskogo gorodskogo prava) ["Strangers" in the Medieval City (Based on the Materials of the Freiburg Municipal Law)]. Vestnik Volgogradskogo gosudarstvennogo universiteta. Seriya 4, Istoriya. Regionovedenie. Mezhdunarodnye otnosheniya [Science Journal of Volgograd State University. History. Area Studies. International Relations], 2014, vol. 19, no. 1, pp. 22-29. DOI: http:// dx.doi.org/10.15688/jvolsu4.2014.1.3

3. Varyash O.I. Gorodskoe pravo i pravo v gorode kak faktor edineniya [City Law and Law in the
City as a Factor of Unity]. Gorod v srednevekovoy tsivilizatsii Zapadnoy Evropy. T. 3. Chelovek vnutri gorodskikh sten. Formy obshchestvennykh svyazey [City in the Medieval Civilization of Western Europe. Vol. 3. The Man inside the City Walls. Forms of Public Relations]. Moscow, Nauka Publ., 2000, pp. 232-253.

4. Gorodskoe pravo Frayburga [City Law of Freiburg]. Srednevekovyy gorod: pril. $k$ ezhegodniku «Srednie veka», 2005, vol. 1, pp. 17-40. (parallelnyy tekst).

5. Negulyaeva, T. M. Zarozhdenie pravosoznaniya i chuvstva lichnosti u nemetskikh byurgerov v XII-XIII vekakh [Origin of Legal Awareness and Feeling of Personality among German Burghers in the $12^{\text {th }}-13^{\text {th }}$ Centuries]. Gorod $v$ srednevekovoy tsivilizatsii Zapadnoy Evropy. T. 3. Chelovek vnutri gorodskikh sten. Formy obshchestvennykh svyazey [City in the Medieval Civilization of Western Europe. Vol. 3. The Man inside the City Walls. Forms of Public Relations]. Moscow, Nauka Publ., 2000, pp. 254-259.

6. Pravo g. Kelna [The Law of the City of Cologne]. Negulyaeva T.M., Solodkova L.I., eds. Srednevekovoe gorodskoe pravo XII - XIII vekov. Sbornik tekstov [Medieval City Law of the $12^{\text {th }}-13^{\text {th }}$ Centuries: Collected Texts]. Saratov, Izd-vo Saratovskogo un-ta, 1989, pp. 61-93.

7. Solodkova L.I. Gorodskaya obshchina: edinstvo i protivorechiya [City Community: Unity and Contradictions]. Srednevekovyy gorod, 2004, vol. 16, pp. 35-41.

8. Solodkova L.I. Ranniy Keln: sotsialnoekonomicheskoe razvitie i osvoboditelnaya borba gorozhan (XI-XIII vv.) [Early Cologne: SocioEconomic Development and the Liberation Struggle of Citizens (11 th $-13^{\text {th }}$ cc. $\left.)\right]$. Saratov, Izd-vo Saratovskogo un-ta, 1991. $148 \mathrm{p}$.

9. Blattmann M. Die Freiburger Stadtrechte zur Zeit der Zähringer. Bd. 1-2. Freiburg - Würzburg, Verlag Ploetz, 1995. 772 p.

10. Büttner H. Freiburg und das Kölner Recht. Zeitschrift des Breisgau-Geschichtsverein (,,Schauins-Land"), 1954, Hf. 72, pp. 7-10.

11. Feger O. Das älteste Freiburger Stadtrecht im Rahmen der südwestdeutschen Städteentwicklung. Zeitschrift des Breisgau-Geschichtsverein (,,Schauins-Land"), 1963, Hf. 81, pp. 18-31.

12. Freiburgs Geschichte in Zitaten. URL: http:// www.freiburgs-geschichte.de/1000-1218_Anfaenge. htm (accessed February 1, 2017).

13. Gaupp E.Th. Über deutsche Städtegründung, Stadtverfassung und Weichbild im Mittelalter, besonders über die Verfassung von Freiburg i. B., verglichen mit der Verfassung von Köln. Jena, F. Frommann, 1824.436p.

14. Huber E. Kölnisches Recht in den Zähringerstädten. Zeitschrift für Schweizerisches Recht, 1882, Bd. 22, pp. 3-21. 
15. Knefelkamp U. Über Rechtsbeziehungen zwischen Köln und Freiburg im Mittelalter. Zeitschrift des Breisgau-Geschichtsvereins (,, Schau-ins-Land“), 1982, Hf. 101, pp. 87-96.

16. Mayer-Edenhauser Th. Das Recht der Liegenschaftsübertragung in Freiburg im Breisgau. Freiburg, Josef Waibel Verlagsbuchh., 1937. 354 p.

17. Rietschel S. Neue Studien über die älteren Stadtrechte von Freiburg im Breisgau mit einer vergleichenden Ausgabe der lateinischen Stadtrechtstexte des 13. Jahrhunderts. Festgabe der Tübinger Juristenfakultät für Friedrich von Thudichum zum Fünfzigjährigen Doktorjubiläum 19. August 1907. Tübingen, Verlag der H. Laupp'schen Buchhandlung, 1907. 45 p.

18. Schlesinger W. Das alteste Freiburger Stadtrecht Überlieferung und Inhalt. Zeitschrift der Savigny-Stiftung für Rechtsgeschichte: Germanistische Abteilung, 1966, bd. 83 , pp. $63-126$.
19. Schreiber H. Freiburg im Breisgau mit seinen Umgebunden. Freiburg, Herdersche Kunst- und Buchhandlung, 1832. $58 \mathrm{p}$.

20. Schreiber H. Merkwürdigere bürgerliche Einrichtungen. I. Das Glocken-oder Blutgericht. Freiburger Adresskalender für das Jahr 1826. Freiburg, Herder'sche Kunst- und Buchhandlung, 1826,265 p.

21. Schwineköper B. Bonn, Köln und Freiburg im Breisgau. Bemerkungen zu den mittelalterlichen Beziehungen der Städte. FS Ennen, E. Bonn, Ludwig Röhrscheid Verlag, 1972, pp. 471-489.

22. Stülpnagel W. Über neuere Arbeiten zu Fragen der Freiburger Stadtgründung. Zeitschrift des Breisgau-Geschichtsverein (,Schau-ins-Land“), 1970, Hf. 88, pp. 5-22.

23. Schreiber H., ed. Urkundenbuch der Stadt Freiburg im Breisgau. Bd. I, Abt. 1-2. Freiburg, Herder'sche Kunst- und Buchhandlung, 1828. 556 p.

\section{Information About the Author}

Pavel A. Blokhin, Candidate of Sciences (History), Associate Professor, Department of Foreign History and Regional Studies, Astrakhan State University, Tatishcheva St., 20a, 414056 Astrakhan, Russian Federation, pavelblochin@yandex.ru, http://orcid.org/0000-0002-5104-755X

\section{Информация об авторе}

Павел Александрович Блохин, кандидат исторических наук, доцент кафедры зарубежной истории и регионоведения, Астраханский государственный университет, ул. Татищева, 20a, 414056 г. Астрахань, Российская Федерация, pavelblochin@yandex.ru, http://orcid.org/0000-00025104-755X 